$14^{\text {th }}$ International Conference on

AEROSPACE SCIENCES \& AVIATION TECHNOLOGY,

ASAT - 14 - May 24 - 26, 2011, Email: asat@mtc.edu.eg

Military Technical College, Kobry Elkobbah, Cairo, Egypt

Tel: +(202) 24025292-24036138, Fax: + (202) 22621908

\title{
Optimization of PV-Hydrogen Electrolyzes System
}

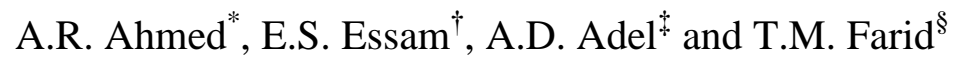

\begin{abstract}
In this work, an electrolyze system is considered to produce Hydrogen $\left(\mathrm{H}_{2}\right)$ using photovoltaic (PV) panels. The system was experimentally installed and tested under the weather conditions of Cairo. Many PV modules with different specifications of current and voltage were tested for individual loads. One of PV modules that have the maximum current with minimum voltage can produce the highest amount of Hydrogen. In addition, the parameters of $(\mathrm{KOH})$ concentration in water and the apart-distance between the electrodes were studied. The apart-distance of $5 \mathrm{~cm}$ between the electrodes was found as optimized distance that produces more $\mathrm{H}_{2}$ quantity. Moreover, a $\mathrm{H}_{2}$-cell of $20 \times 15 \times 13 \mathrm{~cm}^{3}$ has higher $\mathrm{H}_{2}$ production than the size of $6 \times 6 \times 24 \mathrm{~cm}^{3}, 24 \times 6 \times 24 \mathrm{~cm}^{3}$ and $24 \times 24 \times 24 \mathrm{~cm}^{3}$ cells. It is obtained that the optimal system that considers the above efficient conditions must have a PV module with high current and small voltage.
\end{abstract}

Keywords: PV, hydrogen, optimization, solution concentration, apart-distance, cell size

\section{Nomenclature}

A PV module area $\left(\mathrm{m}^{2}\right)$

D Apart distance $(\mathrm{cm})$

E calorific value for hydrogen $(\mathrm{J} / \mathrm{kg})$

$\mathrm{G}$ total solar radiation $\left(\mathrm{W} / \mathrm{m}^{2}\right)$

I load current (Ampere)

$\mathrm{I}_{\mathrm{sh}}$. Short circuit current (Ampere)

MPPT Max power point

$\mathrm{PH} \quad$ Alkaline measure unit

Q Hydrogen volume flow rate $(\mathrm{mL} / \mathrm{min})$

$\mathrm{T}_{\mathrm{s}} \quad$ PV surface temperature $\left({ }^{\circ} \mathrm{C}\right)$

V Load voltage (Volt)

$\mathrm{V}_{\text {open }}$ Open voltage (Volt)

$\eta_{t} \quad$ overall system efficiency

\footnotetext{
* Engineer, Faculty of Engineering, Mattaria, Helwan University, 11718 Cairo, amadoo77@yahoo.com.

$\dagger$ Assoc. Prof., Solar Energy Dept., National Research Centre, Tahrir St., Dokki, Cairo, essamahame@hotmail.com

$*$ Assoc. Prof., Faculty of Engineering, Om El koura University Saudi Arabia, 11718 Cairo, adel_abdeldayem@hotmail.com.

$\S$ Assoc. Prof., Faculty of Engineering, Arab Academy for Science and Engineering, Cairo, tantmfarid@hotmail.com
} 


\section{Introduction}

The economic growth of modern industrialized society has been based on the utilization of energy locked in fossil fuels. At the present time, about $80 \%$ of the world energy demand is met by fossil fuels-coal, petroleum and natural gas. However, consumption of fossil fuels has become a destructive force, locally because of emissions, spills and leaks, and strip mining, regionally because of pollutants' dispersion and acid rains, and even globally because of carbon dioxide accumulation and threatening consequences such as global warming, climate changes and sea level rise. Known reserves of oil and natural gas are about $8 \times 10^{18} \mathrm{~J}$, which would be enough for the next 40 years at the current consumption rate. The demand for energy continues to rise because of the continuing increase in world population and because of the growing demand by developing countries in order to improve their living standard. Hydrogen is another energy currency, which supplements electricity very well and satisfies all other requirement that could be imposed on the energy carriers of the future. Hydrogen has some unique properties, which in conjunction with electricity make it an ideal energy carrier or fuel $[1,2]$.

Among the renewable energy sources, the solar energy has been widely utilized in power generation. The photovoltaic (PV) generation is one of the most useful applications of the solar energy. Photovoltaic power generation, which directly converts solar radiation into electricity, contains many significant advantages such as inexhaustible and pollution-free, silent and has no rotating parts, and size-independent electricity conversion efficiency. Positive environmental effect of photovoltaic is replacing electricity generated in more polluting way or providing electricity where none was available before. With increasing the installation of solar photovoltaic devices, various anti-pollution apparatuses can be operated by solar PV power. So it is used as source of electricity for hydrogen production in this work.

The PV electric power has been used as a source of electric power for hydrogen production with different scales. M. A. Rocheleau reported on the performance, safety, and maintenance issues of a photovoltaic (PV) power plant that uses hydrogen energy storage. After more than 3900 hours, the system has an excellent safety and performance record with an overall electrolyzer efficiency of $76.7 \%$, a PV efficiency of $8.1 \%$, and a hydrogen production efficiency of $6.2 \%$ [3]. E. Suzuki et al. have been connecting the series-connected solar cell externally to the hydrogen and the oxygen evolution electrodes. The conversion efficiency of $3.0 \%$ from the solar to hydrogen chemical energy was obtained and can be expected to be improved further by optimizing the system [4]. E. Suzukia et al. fabricated a photovoltaic water electrolysis device, which was durable for more than $18 \mathrm{~h}$ electrolysis by irradiation in the $\mathrm{KOH}$ electrolyte at $\mathrm{pH} 13$ at conversion efficiency from solar to hydrogen energy of $2.5 \%$ [5]. Shenawy et al. presented a small PV power system for hydrogen production using the photovoltaic module connected to the hydrogen electrolyzer with and without maximum power point tracker. It is found that the average electrolyzer efficiencies are $60 \%$ and $50 \%$ in case of direct coupling and with the MPPT, while the overall system efficiencies are found to be $1.5 \%$ and $2.3 \%$ for both cases, respectively [6]. El Shenawy et al. (2006) based on a typical year of meteorological conditions of Cairo (Egypt) the variation of monthly average solar energy incident on the surfaces of PV modules mounted facing south with $30^{\circ}$ tilt angles. The monthly average incident solar energy has a maximum value of $6.72 \mathrm{~kW} . \mathrm{h} / \mathrm{m}^{2}$.day during summer season, while it has a minimum value of $4.49 \mathrm{~kW} . \mathrm{h} / \mathrm{m}^{2}$.day during winter season. During spring and autumn seasons, it is found that the average solar energy monthly incident on PV modules has an average value of $5.8 \mathrm{~kW} \cdot \mathrm{h} / \mathrm{m}^{2}$.day. According to variation in the average maximum output energy of PV modules which was mounted facing south with $30^{\circ}$ tilt, it is clear that the photovoltaic module current is directly affected by the solar radiation intensity as well as increasing the electrolyzer current increases the hydrogen production flow 
rate, with the proposed small scale system has the electrolyzer box of $4500 \mathrm{~cm}^{3}$ containing $80 \%$ of its volume electrolyte solution with electrodes of $2 \mathrm{~cm}^{2}$ cross section area gives an average 300 liters of hydrogen monthly [7].

This work is aimed to design an optimal system to produce the hydrogen from an electrolyze system. The optimization process is divided into six stages where the first four are working under constant opening voltage of 4.08 (power supply). Work has the following sequence:

- Studying the conductivity of electrolysis using $\mathrm{KOH}$ and $\mathrm{NaCl}$ to maximize the hydrogen production.

- Optimize the distance between the electrodes to increase the current drawn.

- Study the effect of electrolysis size solution on hydrogen production.

- Use different electrodes materials.

- Measuring the I-V curve for every module and determine the maximum power point.

- Determine the optimal construction of the PV module to determine the highest efficiency.

\section{Experimental Setup}

The overall system as indicated in figure 1 consists of:

- Six Photovoltaic modules

Six different modules are used to get the most optimized one for direct connection with hydrogen cells. All of them are fixed to the south direction and tilted $30^{\circ}$ with the horizontal. Specifications of modules are:

- Module 1 has the power $8 \mathrm{~W}, \mathrm{~V}_{\text {open }}=4 \mathrm{~V}, \mathrm{I}_{\mathrm{sh}}=6 \mathrm{~A}$ and it is single or mono crystal module.

- Module 2 has the power $75 \mathrm{~W}, \mathrm{~V}_{\text {open }}=21.6 \mathrm{~V}, \mathrm{I}_{\mathrm{sh}}=4.67 \mathrm{~A}$ and it is single or mono crystal.

- Module 3 has the power $50 \mathrm{~W}, \mathrm{~V}_{\text {open }}=22 \mathrm{~V}, \mathrm{I}_{\text {sh. }}=5 \mathrm{~A}$ and it is single or mono crystal.

- Module 4 has the power $64 \mathrm{~W}, \mathrm{~V}_{\text {open }}=27.1 \mathrm{~V}, \mathrm{I}_{\mathrm{sh}}=4.8 \mathrm{~A}$ and it is amorphous module.

- Module 5 has the power $20 \mathrm{~W}, \mathrm{~V}_{\text {open }}=18 \mathrm{~V}, \mathrm{I}_{\mathrm{sh}}=1.9 \mathrm{~A}$ and it is mono crystal.

- Module 6 has the power $45 \mathrm{~W}, \mathrm{~V}_{\text {open }}=22 \mathrm{~V}, \mathrm{I}_{\mathrm{sh}}=3.6 \mathrm{~A}$ and it is mono crystal.

- Four hydrogen cells with different solution size:

Four hydrogen tanks were fabricated from Perspex. This material was selected because of its ability to withstand the pressure and temperature. Moreover, it is considered as dielectric for electric power and it has high resistance to corrosion. The considered cells have the following sizes:

- Cell 1 is $6 \times 6 \times 24 \mathrm{~cm}\left(864 \mathrm{~cm}^{3}\right)$.

- Cell 2 is $24 \times 6 \times 24 \mathrm{~cm}\left(3456 \mathrm{~cm}^{3}\right)$.

- Cell 3 is $20 \times 13 \times 15 \mathrm{~cm}\left(3900 \mathrm{~cm}^{3}\right)$.

- Cell 4 is $24 \times 24 \times 24 \mathrm{~cm}\left(13824 \mathrm{~cm}^{3}\right)$.

- Measuring devices of hydrogen flow rate, current and voltage. 


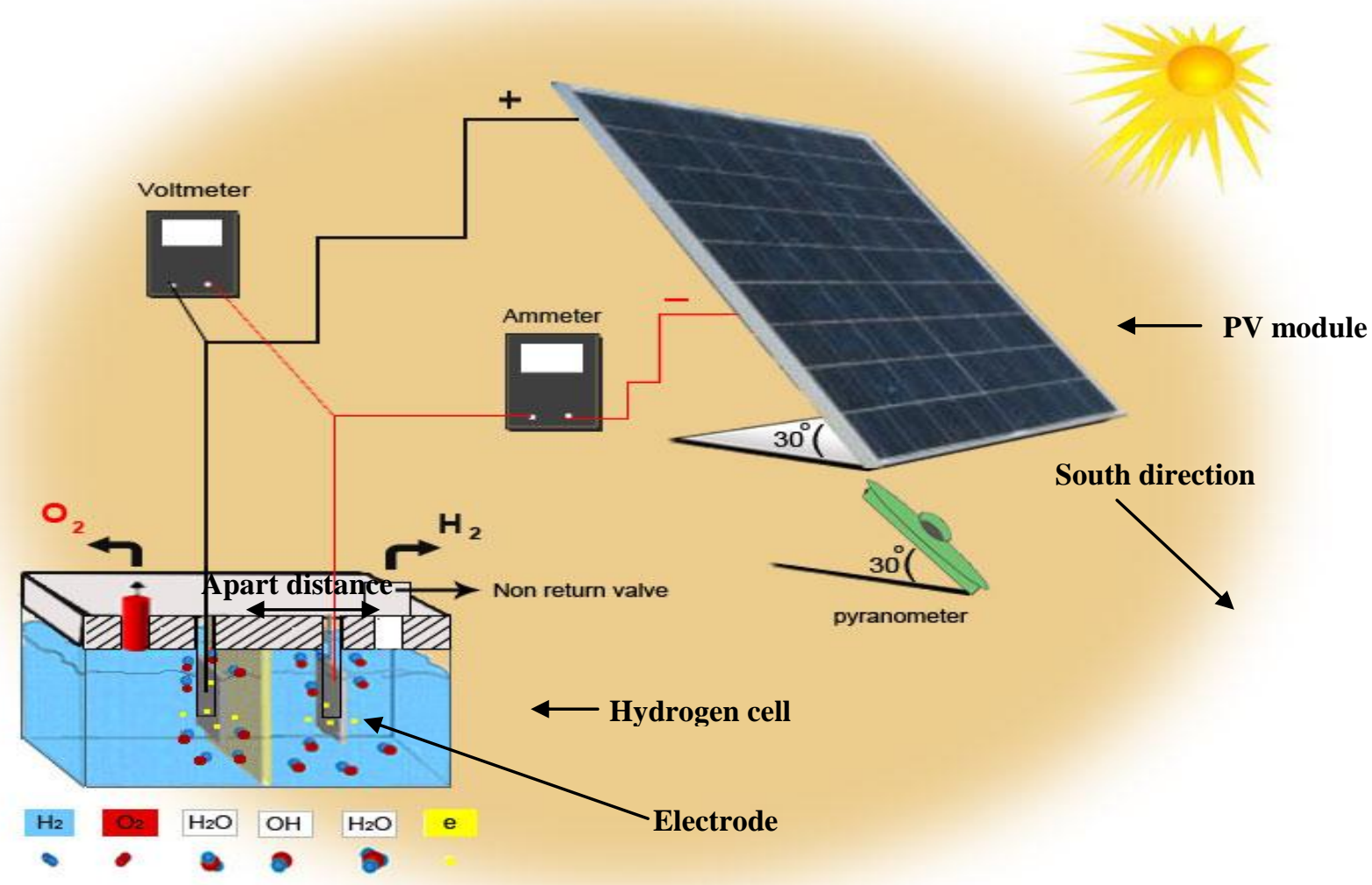

Figure 1 Schematic diagram of the PV-Hydrogen generation system

\section{Measuring Instruments}

The overall system parameters are measured accurately and recorded continuously for data storing as follows:

- The PV module and the electrolyzer voltages and currents are measured using digital voltmeters and ammeters with accuracies of 0.01 Volt and 0.001 Ampere, respectively.

- A thermopile pyranometer of type Kipp \& Zonen (model CM5-774035) is used to measure the solar radiation intensity. The pyranometer is mounted at the PV module structure and parallel to the module surface.

- A type $\mathrm{K}$ thermocouple is used to measure the PV module surface and ambient temperatures.

- The hydrogen flow rate is measured with Wheaton Scientific Digital Flowmeter with accuracy of $0.1 \mathrm{~mL} / \mathrm{min}$.

\section{Results and Discussion}

\subsection{Optimization of the PV-Hydrogen System}

The hydrogen generation system simply consists of a PV module connected to a hydrogen cell. Optimizing of PV performance includes arrangement of PV cells to maximize the output gain. In addition, optimization of the hydrogen cell considers the following items:

- Electrolyte mixture and salt concentration,

- Electrodes material and apart-distance between them,

- And hydrogen-cell size (solution size). 
In the following subsections the above parameters are explained.

\subsubsection{Conductivity of electrolysis}

To use the distilled water in hydrogen production, there is need to increase its electrical conductivity by adding some salts like Potassium Hydroxide $(\mathrm{KOH})$ and Sodium Chloride $(\mathrm{NaCl})$. As Potassium $(\mathrm{K})$ and Sodium $(\mathrm{Na})$ have the maximum conductivity according to periodic table, therefore they are mixed with water for different concentrations as shown in figures 2 and 3 to illustrate its effect on the system performance and to find the optimized concentration for each salt. Moreover both two salts are compared to obtain which has higher production. From figures 2 and 3 it is clear that hydrogen production for $\mathrm{NaCl}$ is less than $\mathrm{KOH}$ solution in the form of current drawn and hydrogen flow rate produced.

Accordingly, it is illustrated that the optimized concentration of $\mathrm{KOH}$ in distilled water which gives the highest electrical current drawn and maximum flow rates of hydrogen is at $30 \%$. For this percent the distilled water gets its best saturation of $\mathrm{KOH}$ and has the maximum conductivity. For that concentration it is obtained about 3 Ampere current drawn and $70 \mathrm{~mL} / \mathrm{min}$ hydrogen gas under its conditions of input current and voltage.

\subsubsection{Distance between electrodes}

The apart-distance between the electrodes affects the hydrogen-cell production and accordingly affects the system performance. Three apart-distances between the electrodes are considered, 3,5 and $7 \mathrm{~cm}$. As explained in figure 4 the hydrogen flow rate is estimated for the three distances. It is clear that the apart-distance of $5 \mathrm{~cm}$ has higher flow rate than the others where the distances of $3 \mathrm{~cm}$ and $7 \mathrm{~cm}$ have the same flow rate. That conclusion cannot be generalized for any hydrogen-generation system but it is specified only for the considered system. In fact that can be understood as the hydrogen-cell conductivity is modified for that distance. In the apart distance $3 \mathrm{~cm}$ the overall reaction could not be completed, because the electrons are produced with rate more than the reaction of separation happens. But in case of $7 \mathrm{~cm}$ distance, it is so far for electrons to transfer to produce $\mathrm{H}_{2}$ and that takes more time than $5 \mathrm{~cm}$, which is considered as the optimum distance.

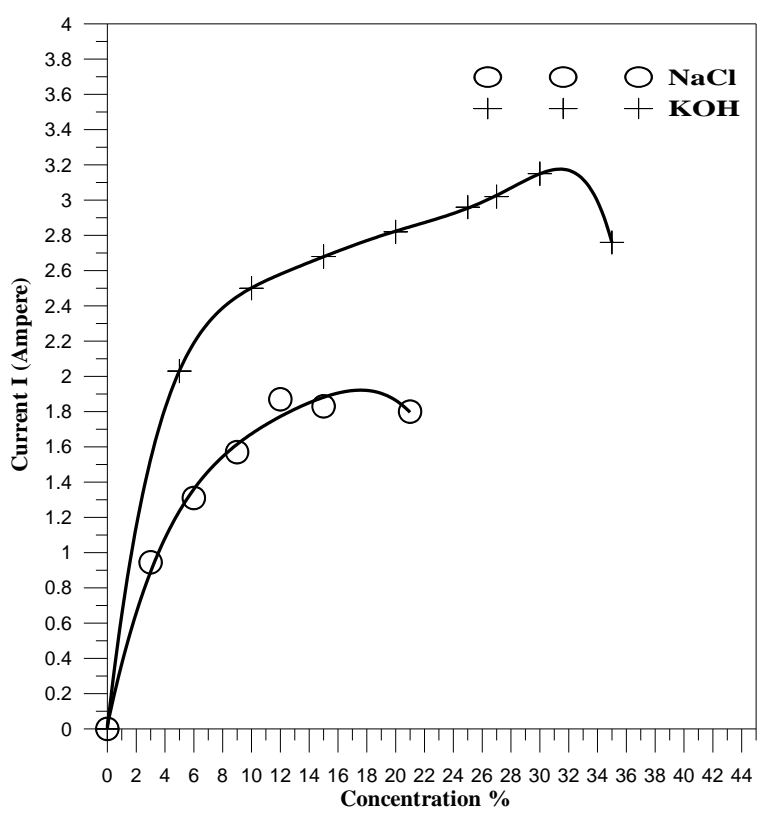

Figure 2 Current drawn vs. $\mathrm{NaCl}$ and $\mathrm{KOH}$ solution concentrations 


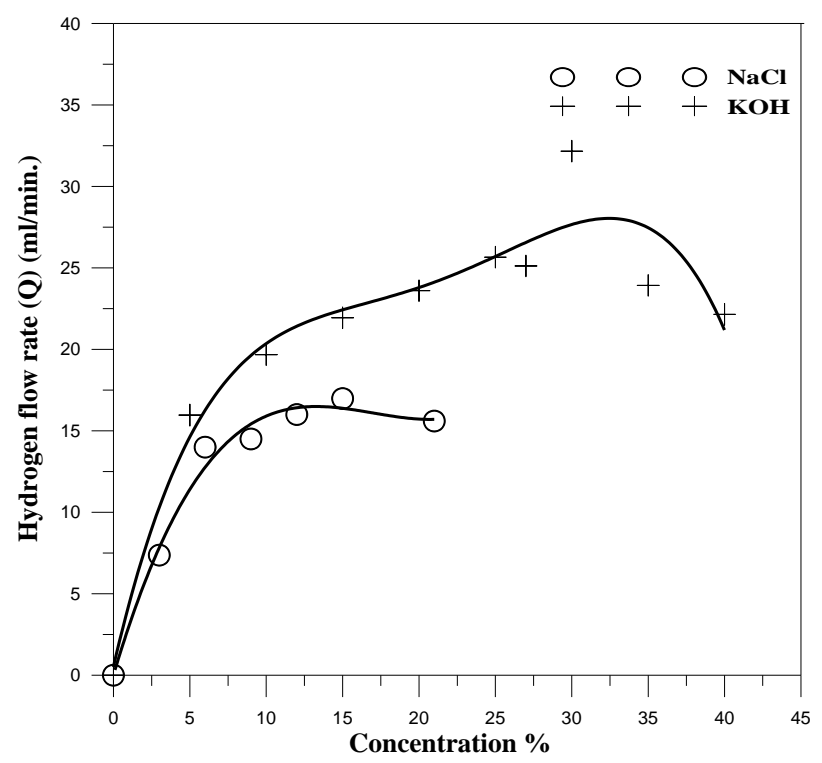

Figure 3 Hydrogen-gas flow rate vs. $\mathrm{NaCl}$ and $\mathrm{KOH}$ solution concentrations

\subsubsection{The size of hydrogen-cell (solution size)}

As explained before three hydrogen-cells were considered with different sizes and dimensions. The electrodes material, and dimensions and the electrolyte used are the same and under the same conditions of current and voltage. From figure 5 it is clear that cell 3 has $20 \times 15 \times 13 \mathrm{~cm}\left(3900 \mathrm{~cm}^{3}\right)$ which has the highest flow rate of hydrogen gas and maximum current drawn. The hydrogen production increases by increasing the cell volume from cell-1 to cell-3 and decreases for cell-4 at which the hydrogen-cell resistance is huge due to large size. According to result illustrated in figure 5 the increase in solution size will increase the flow rate of $\mathrm{H}_{2}$ production and that can be due to:

a. Increase the electron emission.

b. Speeding the overall reaction due to increase of contact area of electrode.

That will happen till cell 4 at which it decays due to increase in the resistance of the solution, where the electrolyte surface area is being small relative to the volume of cell 4 .

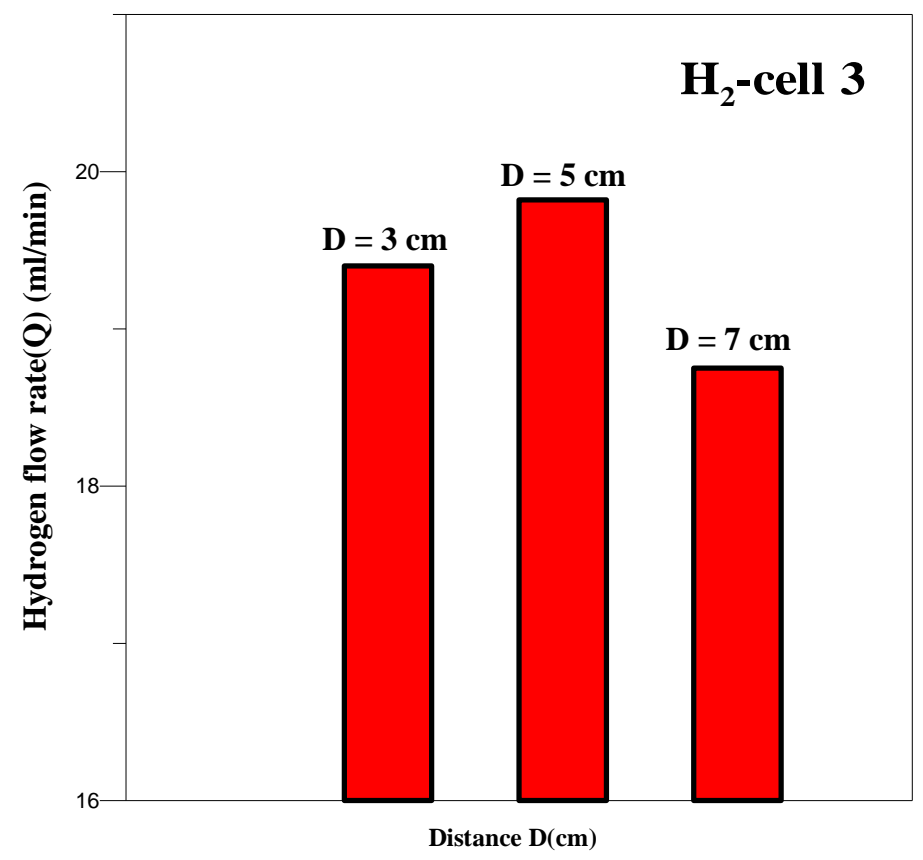

Figure 4 Hydrogen-cell performance for different apart-distances of electrodes 


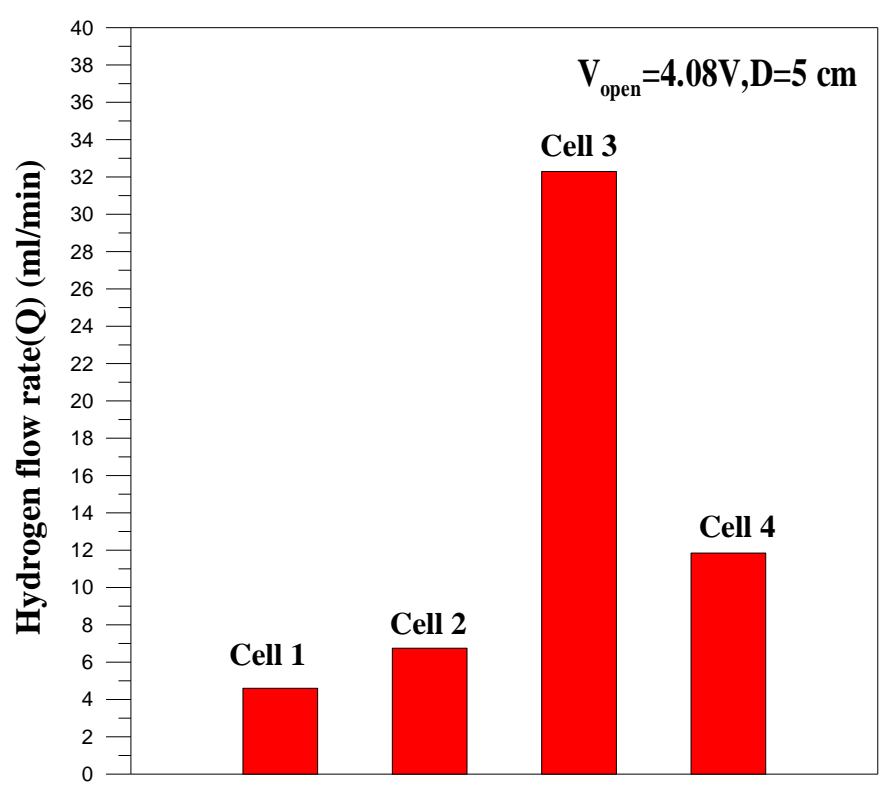

Hydrogen volumes cells

Figure 5 Flow rate of hydrogen versus the size of hydrogen-cell

\subsubsection{Selection of the PV modules}

The six PV modules explained before are used to supply power into one hydrogen-cell to find the efficient one that has the highest hydrogen production. The modules have different powers and structures. For every module, the total solar radiation, ambient temperature, PV surface temperature, output current, PV power and the flow rate of hydrogen were measured. The hydrogen flow rate was measured under the weather conditions of solar radiation and ambient temperature as shown in figure 6. The system overall efficiency is also estimated. The electrolyzer efficiency and the overall system efficiency for the direct coupling system are calculated according to the following equations [3]:

$$
\eta_{t}=(\mathrm{Q} \times \mathrm{E}) /(\mathrm{G} \times \mathrm{A})
$$

According to this equation the system overall efficiency was plotted as in figure 7 .

Naturally the hydrogen flow rate is increased with increasing the input solar radiation. That fact is reversed in the case of efficiency as presented in figure 7. The system efficiency is lowered under the higher solar radiation. That is because the PV efficiency is decreased due to higher ambient temperature in that case. From figures 4 and 5 which describe the comparison between all modules for the two important parameters, flow rate and total efficiency, the module 1 has the maximum flow rate and maximum efficiency under the same conditions, because this module is characterized with high current output and low voltage which is needed to improve both total efficiency and flow rate of hydrogen, where the voltage needed to dissolve the molecule of water is $1.45 \mathrm{~V}$. 


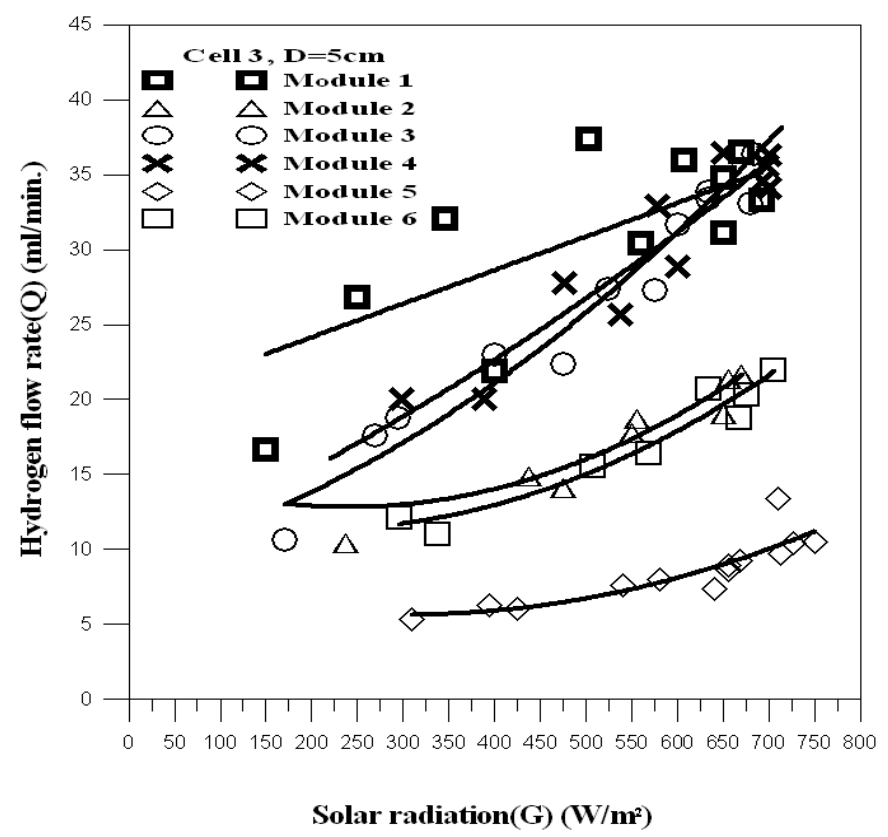

Figure 6 Comparison between the six modules for flow rate of Hydrogen

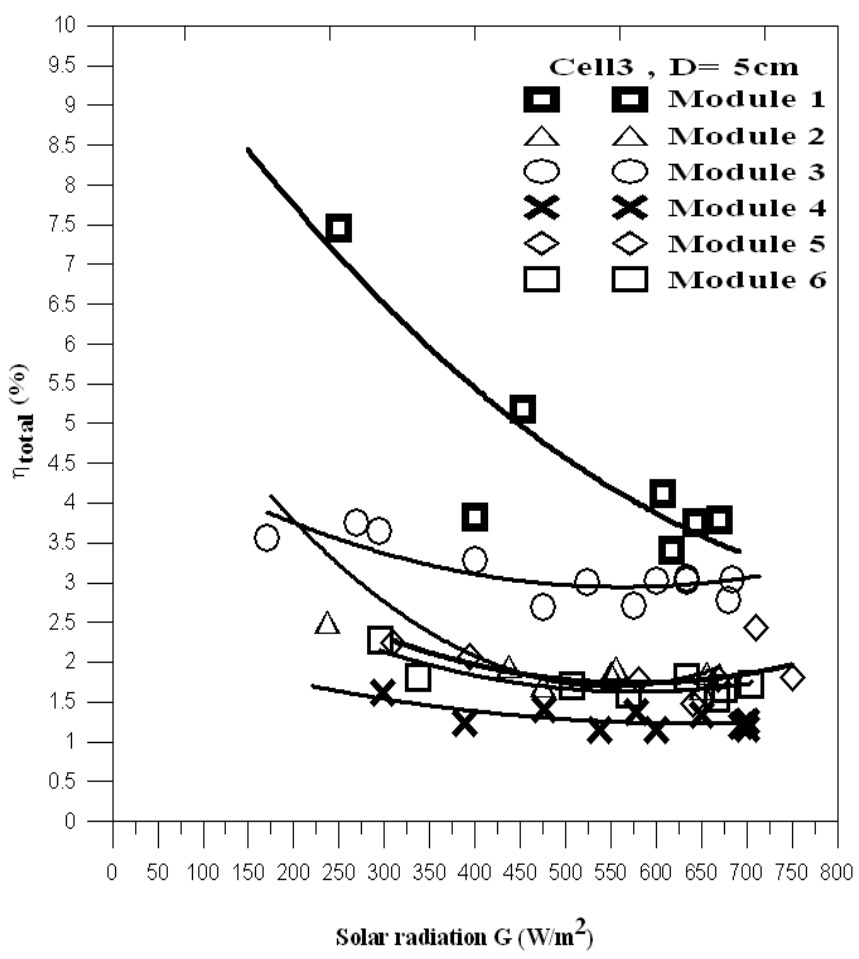

Figure 7 Comparison between 6 modules for $\eta_{\text {total }}$

\subsection{Visualization of the Optimal System Performance}

As discussed in the above subsections the PV-hydrogen generation system was optimized, considering both PV and hydrogen-cell. From that discussion, it is clear that the optimal system that can be efficiently used and can produce the highest hydrogen generation should have the following specifications:

- Module $1 \mathrm{P}_{\text {max. }}=4.4793 \mathrm{~W}$ (it is measured to produce $\mathrm{I}-\mathrm{V}$ curve and power curve using resistance box as a load), $\mathrm{V}_{\text {max. }}=1.89 \mathrm{~V}, \mathrm{I}_{\max }=2.37 \mathrm{~A}, \mathrm{G}=550 \mathrm{~W} / \mathrm{m}^{2}, \mathrm{~T}_{\mathrm{s}}=49^{\circ} \mathrm{C}$

- Where the Hydrogen cell volume 3 is $20 \times 15 \times 13 \mathrm{~cm}^{3}$.

- Apart-distance $5 \mathrm{~cm}$ of the electrodes. 
- KOH electrolyte with concentration of $30 \%$.

- Electrode of Nickel Chrome.

The performance of the optimal system is visualized as shown in figure 8 . The hydrogen flow rate and system efficiency are estimated under the field conditions of weather and PV. For this system the total efficiency is reached as an average for a day to $8.2 \%$ and flow rate of hydrogen to $37.7 \mathrm{~mL} / \mathrm{min}$. as average. It is clear that the optimized system is able to produce about $39567.07 \mathrm{~mL}$ of hydrogen daily. Figure 9 show the local time with both radiation and accumulated flow rate for a full day in the summer season.

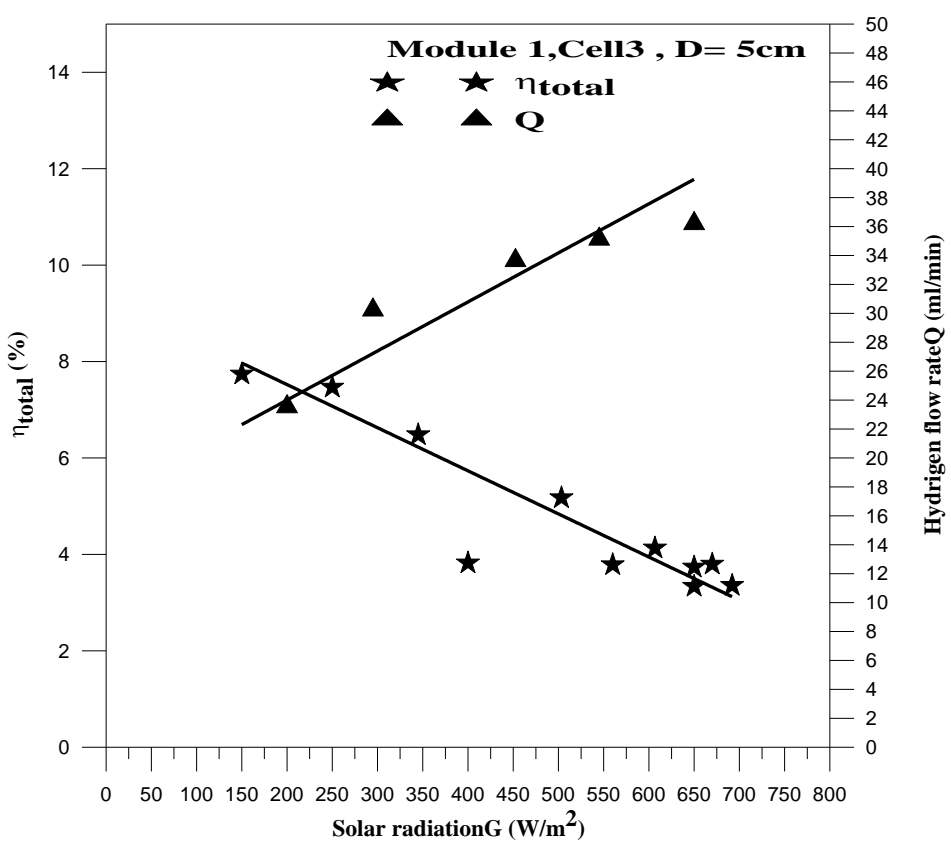

Figure 8 Total efficiency and flow rate of Module 1 for solar radiation variation

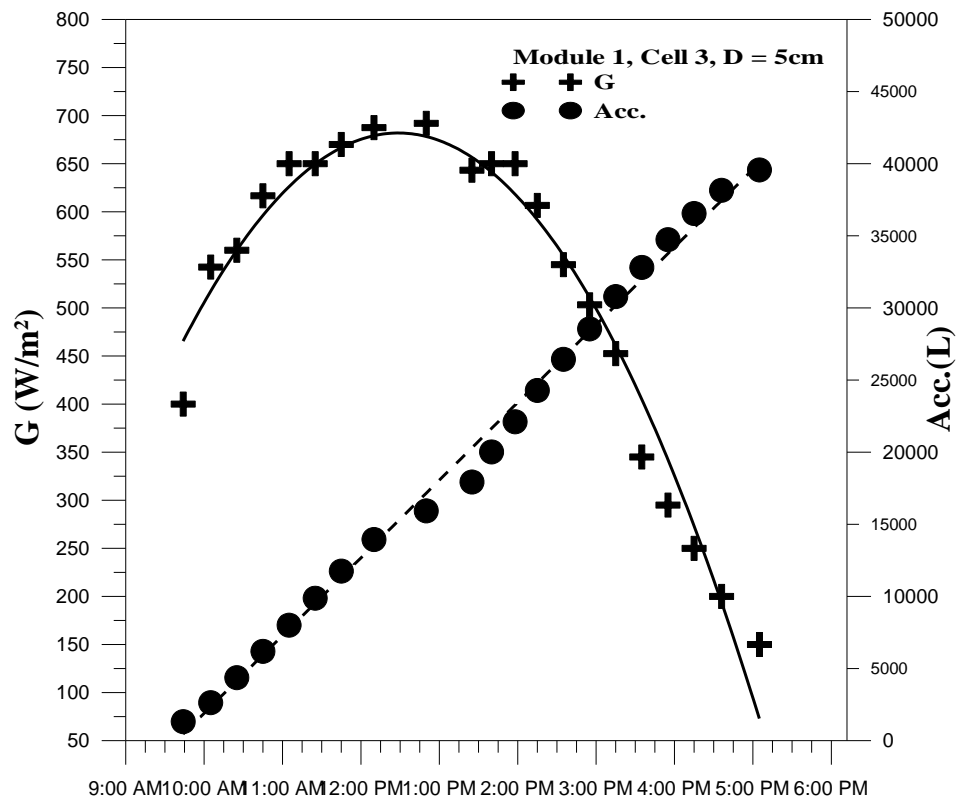

Local Time

Figure 9 The local time with flow rate, solar radiation and accumulated flow rate 


\section{Conclusions}

A PV-hydrogen generation system is optimized by both PV-module and hydrogen cell. It is obtained that the PV module should have higher current and lower voltage. For the hydrogencell, it should have the following characteristics:

- Electrolyte of $\mathrm{KOH}$ with $30 \%$ salt-concentration has higher efficiency than $\mathrm{NaCl}$ due to increasing the conductivity of water.

- The $\mathrm{H}_{2}$-cell of $20 \times 15 \times 13 \mathrm{~cm}^{3}$ has higher $\mathrm{H}_{2}$ production than different cells sizes.

- The apart-distance of 5-cm is found the best distance that produces more $\mathrm{H}_{2}$ quantity.

- 6 different modules with difference in both type and power are installed to the system to make optimization for the hydrogen production and increase the total efficiency.

Finally, an empirical equation for the optimal hydrogen generation system was estimated to predict the system performance for this case.

\section{References}

1. J. O'M. Bockris, and T. N. Verziroglu, A Solar-Hydrogen Energy System for Environmental Compatibility, Environmental Conservation, Vol. 12, pp. 105-118, 1985.

2. T. N. Veziroglu and F. Barbir, Hydrogen: The Wonder Fuel. Int. J. Hydrogen Energy. Vol. 17, No.6, pp. 391-404, 1992.

3. M. A. Rocheleau, Operating Experience with Photovoltaic-Hydrogen Energy System: The 10th World Hydrogen Energy Conference, Cocoa Beach, Florida, June 20-24, 1994.

4. E. Suzukia et al., Photovoltaic Water Electrolysis Using the Sputter-Deposited A-Si/C-Si Solar Cells, International Journal of Hydrogen Energy 26 (2001) 661-664.

5. E. Suzukia et al., One Chip Photovoltaic Water Electrolysis Device, Int. J. Hydrogen Energy, No. 28, pp. 1167-1169, 2003.

6. G. E. Ahmad and E. T. El Shenawy, Optimized Photovoltaic System for Hydrogen Production, Renewable Energy, No. 31, pp. 1043 - 1054, 2005.

7. E. T. El Shenawy et al, Annual Performance of Photovoltaic Hydrogen Electrolyzer System in Egypt, Renewable Energy, No. 33, pp. 1042 - 1069, 2006. 